REFLEKSI HUKUM

Jurnal Ilmu Hukum
p-ISSN 2541-4984 | e-ISSN 2541-5417

Volume 5 Nomor 2, April 2021, Halaman 237-254

DOI: https://doi.org/10.24246/jrh.2021.v5.i2.p237-254

Open access at: http:// ejournal.uksw.edu/refleksihukum

Penerbit: Fakultas Hukum Universitas Kristen Satya Wacana

\title{
PERLINDUNGAN HUKUM RAHASIA DAGANG DALAM PERJANJIAN FRANCHISE COCOYO
}

\author{
Velliana Tanaya \\ Fakultas Hukum Universitas Pelita Harapan|velliana.tanaya@uph.edu \\ Jessica Vincentia Marpaung \\ Fakultas Hukum Universitas Pelita Harapan |jessica.marpaung@uph.edu \\ Audrea Dindya Djohan \\ Fakultas Hukum Universitas Pelita Harapan | audreadindya@gmail.com
}

\author{
A R T I C L E I N F O \\ Article history: \\ Received \\ 9 September 2020 \\ Revised \\ 20 Januari 2021 \\ Accepted \\ 10 Mei 2021 \\ Kata-kata Kunci: \\ Perjanjian Franchise \\ Cocoyo; Rahasia \\ Dagang; \\ Perlindungan \\ Hukum.
}

\section{Keywords:}

Cocoyo Franchise Agreement; Trade Secrets; Legal Protection

\begin{abstract}
Abstrak
Waralaba makanan dan minuman merupakan salah satu peluang bisnis yang berkembang di Indonesia. Salah satu unsur penting dalam industri ini adalah rahasia dagang. Dalam prakteknya, semua perjanjian waralaba memiliki satu atau beberapa pasal yang mengatur ketentuan mengenai pemberian hak rahasia dagang dan pelanggaran rahasia dagang. Namun pada kenyataannya, dalam perjanjian waralaba Cocoyo tidak ada pengaturan mengenai rahasia dagang sehingga tidak memberikan perlindungan hukum bagi rahasia dagang Cocoyo. Penelitian ini menggunakan metode penelitian hukum normatif. Penelitian ini akan menganalisis bagaimana bentuk perlindungan hukum terhadap rahasia dagang dalam perjanjian waralaba Cocoyo. Kesepakatan untuk memberikan dan merahasiakan rahasia dagang Cocoyo bersifat lisan. Walaupun bersifat lisan, rahasia dagang Cocoyo tetap dilindungi oleh hukum.
\end{abstract}

\section{Abstract}

The food and beverage franchise is one of the thriving businesses in Indonesia. In this industry, one of the essential elements is trade secrets. In practice, all franchise agreements have one or several articles governing the provisions regarding granting the trade secrets rights and violations of trade secrets. However, in reality, in the Cocoyo franchise agreement, there is no clause regarding its trade secrets, so it does not provide legal protection for Cocoyo's trade secrets. This research uses the normative legal research method in which this study will analyze the forms of legal protection against trade secrets in the Cocoyo franchise agreement. The agreement to protect and disclose Cocoyo's trade secrets confidential was verbal. Although verbal, its trade secrets are still covered by the law. 


\section{PENDAHULUAN}

Waralaba (yang selanjutnya disebut franchise) adalah hak khusus yang dimiliki oleh orang perseorangan atau badan usaha terhadap sistem bisnis dengan ciri khas usaha dalam rangka memasarkan barang dan/atau jasa yang telah terbukti berhasil dan dapat dimanfaatkan dan/atau digunakan oleh pihak lain berdasarkan perjanjian franchise. ${ }^{1}$ Perjanjian franchise adalah sebuah perjanjian dimana seseorang atau badan hukum diberikan hak untuk menggunakan merek dagang orang lain atau sebuah konsep bisnis yang dalam menjalankan usaha tersebut didasarkan oleh sebuah perjanjian. Usaha franchise telah ada di Indonesia sejak tahun 1970an dengan ditandai oleh masuknya beberapa restaurant siap saji seperti Kentucky Fried Chicken (KFC), Wendy's dan McDonald's. Usaha franchise ini dianggap sebagai salah satu usaha yang mendorong perekonomian negara, sehingga para pengusaha lokal pun ikut menciptakan franchise lokal dengan merek Es Teler 77 yang dikenal hingga saat ini ${ }^{2}$. Sejak itu pun usaha franchise asing maupun lokal di Indonesia mengalami perkembangan yang pesat.

Perkembangan usaha franchise di Indonesia juga memiliki esensi yang penting dalam perkembangan ekonomi di Indonesia. Pada tahun 2019, tercatat terdapat 2.000 merek franchise asing maupun lokal dengan omzet sekitar Rp.150 Triliun dan diharapkan masih dapat terus bertambah ke depannya. ${ }^{3} \mathrm{Hal}$ ini juga didukung oleh pembukaan Presiden Joko Widodo dalam pameran Indonesia Franchise and SME Expo (IFSE) 2016 di Jakarta Convention Center (JCC) mengatakan bahwa usaha franchise juga dinilai cocok dengan kondisi masyarakat yang ada di Indonesia. ${ }^{4}$

Dilihat dari begitu berperannya usaha franchise dalam perkembangan ekonomi Indonesia, 5 usaha franchise memiliki payung hukumnya sendiri berupa Peraturan Pemerintah No. 42 Tahun 2007 tentang Waralaba (yang selanjutnya disebut PP Waralaba) yang mengatur hal-hal yang perlu diperhatikan dalam pembuatan perjanjian franchise seperti perjanjian harus dalam bentuk tertulis, keterangan yang diberikan oleh pemberi franchise (selanjutnya disebut franchisor) kepada penerima franchise (selanjutnya disebut franchisee) sebelum membuat perjanjian, klausula yang wajib ada dalam perjanjian franchise, jangka waktu perjanjian, pendaftaran perjanjian franchise kepada Direktur Jendral Perdagangan Dalam Negeri hingga berakhirnya perjanjian franchise.

PP Waralaba sendiri mengacu pada Undang-Undang (UU) No. 9 Tahun 1995 tentang Usaha Kecil (pada tahun 2008 di amandemen dengan Undang-Undang No. 20 Tahun 2008 tentang Usaha Mikro, Kecil, dan Menengah), mengingat usaha franchise di Indonesia beberapanya tergolong sebagai Usaha Kecil. Sebelum adanya pengaturan khusus mengenai franchise, usaha franchise di Indonesia merujuk pada

Pasal 1 angka 1 Peraturan Pemerintah Republik Indonesia No. 42 Tahun 2007 tentang Waralaba. Sri Redjeki, 'Waralaba (Franchise) di Indonesia' (2011) 8 (2) Lex Jurnalica 127.

Koran Sindo, 'Omzet Rp150 Triliun, Momentum Emas Ekspansi Bisnis Waralaba' (Oke Finance, 22 April 2019) <https://economy.okezone.com/read/2019/04/22/320/2046337/omzet-rp150triliun-momentum-emas-ekspansi-bisnis-waralaba> diakses 9 September 2020.

4 Gora Kunjana, 'Waralaba, Kekuatan Baru Ekonomi RI' (Investor Daily Indonesia, 26 November 2016) <https://investor.id/archive/waralaba-kekuatan-baru-ekonomi-ri> diakses 9 September 2020.

5 Zil Aidi, dan Hasna Farida, 'Perlindungan Hukum Para Pihak dalam Perjanjian Waralaba Makanan' (2019) 4 (2) Jurnal Cendekia Hukum 207, 208. 
UU No. 9 Tahun 1995 tentang Usaha Kecil. Istilah franchise dalam UU No. 9 Tahun 1995 ditemukan dalam ketentuan yang membahas mengenai kemitraan usaha antara usaha kecil dengan usaha menengah dan besar, dalam pasal 27 UU No. 9 Tahun 1995 juga dijelaskan yang dimaksud dengan pola franchise adalah hubungan kemitraan yang didalamnya pemberi franchise memberikan hak penggunaan lisensi, merek dagang, dan saluran distribusi perusahaannya kepada franchisee dengan disertai bantuan bimbingan manajemen. ${ }^{6}$

Perjanjian franchise merupakan salah satu bentuk perjanjian innominaat atau perjanjian tidak bernama. ${ }^{7}$ Perjanjian tidak bernama adalah perjanjian-perjanjian yang belum ada pengaturannya secara detail di dalam undang-undang, karena tidak diatur dalam Kitap Undang-Undang Hukum Perdata (KUHPerdata) dan Kitab Undang-Undang Hukum Dagang (KUHD). Bentuk perjanjian seperti ini merupakan perjanjian yang timbul, tumbuh, dan berkembang dalam kehidupan bermasyarakat. 8 Lahirnya perjanjian ini di dalam prakteknya adalah berdasarkan asas kebebasan berkontrak dalam mengadakan perjanjian sesuai dengan Pasal 1338 KUHPerdata. Mariam Darus Badrulzaman sebagaimana dikutip oleh Salim HS dalam bukunya mengartikan perjanjian innominaat sebagai berikut: ${ }^{9}$

"Perjanjian-perjanjian yang tidak diatur dalam KUH Perdata, tetapi terdapat di masyarakat. Hal ini adalah berdasar kebebasan mengadakan perjanjian atau partij autonomi yang berlaku dalam perjanjian."

Dasar hukum untuk perjanjian tidak bernama diatur dalam Pasal 1319 KUHPerdata, yaitu yang berbunyi:

"semua perjanjian, baik yang mempunyai nama khusus maupun yang tidak dikenal dengan suatu nama tertentu, tunduk pada peraturan umum yang termuat dalam bab ini dan bab yang lain". ${ }^{10}$

Salah satu usaha franchise yang saat ini digandrungi sebagai bisnis adalah franchise food and beverage (selanjutnya di sebut franchise $F \& B$ ). Food and Beverage $(F \& B)$ merupakan salah satu sektor usaha yang memiliki potensi untuk terus tumbuh dan berkembang. Hal ini dikarenakan franchise $F \& B$ biasanya mengikuti tren-tren baru yang terus-menerus muncul dalam masyarakat, sehingga demand terhadap $F \& B$ tersebut akan terus meningkat. Selain itu, franchise $F \& B$ atau franchise dalam industri lainnya merupakan salah satu cara untuk melakukan bisnis instan yang menguntungkan. Dengan usaha franchise, franchisee tidak perlu memulai bisnis dari awal dan mengembangkan merek lagi dalam pasar. Selain menguntungkan franchisee, franchisor juga diuntungkan karena area pemasaran merek milik franchisor juga akan diperluas. ${ }^{11}$

\footnotetext{
$6 \quad$ Moch Najib, 'Urgensi Pengaturan Waralaba dalam Undang-Undang' (2012) 1 (2) Yustisia 11, 16. Ferry Lasamahu, 'Perlindungan Hukum Terhadap Franchise dalam Perjanjian Waralaba (Studi Kasus: Analisis Putusan Pengadilan antara PT Lingkar Natura Inti dan Natasha Kasakeyan' (2006) 36 (3) Jurnal Hukum dan Pembangunan 306, 308.

$8 \quad$ Lannemey, 'Akibat Hukum Pemutusan Perjanjian Franchise Secara Sepihak Oleh Franchisor Sebelum Berakhirnya Kontrak' (2015) 3 (1) Lex Privatum 161, 163.

$9 \quad$ Salim, Perkembangan Hukum Kontrak Innominaat di Indonesia ( Sinar Grafika Jakarta 2005) 17.

10 Pasal 1319 Kitab Undang-Undang Hukum Perdata.

11 Poppy Indriani dan Yeni Widyanti, 'Prospects Franchise Business Developments in Indonesia (Case Studies of Food Businesses)' [2012] ICEBM UNTAR 143, 146.
} 
Dalam industri $F \& B$, salah satu hal yang penting dan utama adalah rahasia dagang. ${ }^{12}$ Rahasia dagang yang dimaksud meliputi resep makanan atau minuman, alat-alat yang digunakan, sampai dengan cara dan standar pemilik rahasia dagang dalam mengolah dan menyajikan makanan atau minuman yang dijual. Pada prakteknya, semua perjanjian franchise dalam bidang $F \& B$ memiliki satu atau beberapa pasal yang mengatur ketentuan mengenai pelanggaran rahasia dagang. Rahasia dagang ini akan dialihkan kepada franchisee secara hitam diatas putih yang pastinya tidak boleh dibocorkan kepada pihak lain diluar yang diperjanjikan. Namun pada kenyataannya, ternyata pengaturan mengenai rahasia dagang dalam suatu perjanjian franchise tidaklah serinci dan sekompleks itu.

Rahasia dagang merupakan asset yang berharga dalam suatu perusahaan sehingga harus dijaga sifat kerahasiaannya dan mendapatkan perlindungan. Apabila rahasia dagang terungkap pada pihak lain diluar perjanjian maka dapat menimbulkan kerugian bagi penemu rahasia dagang tersebut. Untuk meminimalisir kerugian yang akan terjadi, rahasia dagang dilindungi dengan UU No. 30 Tahun 2000 tentang Rahasia Dagang (yang selanjutnya disebut UU Rahasia Dagang). Pasal 1 angka (1) UU Rahasia Dagang memberikan definisi rahasia dagang sebagai berikut:13 "Rahasia dagang adalah informasi yang tidak diketahui oleh umum di bidang teknologi dan/atau bisnis, mempunyai nilai ekonomi karena berguna dalam kegiatan usaha, dan dijaga kerahasiaannya oleh pemilik rahasia dagang."

Walaupun rahasia dagang merupakan informasi yang bersifat tertutup dan harus dijaga kerahasiaannya, informasi mengenai rahasia dagang tersebut dapat dipindahtangankan dari pemilik kepada orang lain. Dalam Pasal 5 UU Rahasia Dagang, disebutkan bahwa salah satu cara memindahtangankan rahasia dagang tersebut adalah dengan adanya perjanjian tertulis ${ }^{14}$. Sehingga, dalam prakteknya hak rahasia dagang dapat berpindah melalui perjanjian franchise. Pasal $3 \mathrm{PP}$ Waralaba, menyebutkan bahwa salah satu kriteria franchise adalah hak kekayaan intelektual yang telah terdaftar, yang dimaksud hak kekayaan intelektual yang telah terdaftar adalah hak kekayaan intelektual yang terkait dengan usaha seperti merek, hak cipta, paten, dan rahasia dagang, sudah didaftarkan dan mempunyai sertifikat atau sedang dalam proses pendaftaran di instansi yang berwenang. ${ }^{15}$ Dengan demikian, pemberian hak untuk memanfaatkan hak kekayaan intelektual tertentu yang dalam hal ini berupa rahasia dagang, dapat dipenuhi oleh franchisor kepada franchisee.

Penelitian dilakukan terhadap satu usaha franchise berskala UKM yaitu Cocoyo. Cocoyo merupakan salah satu usaha $F \& B$ kecil yang menjual berbagai varian minuman kelapa murni dan telah memiliki beberapa gerai franchise yang tersebar di seluruh Indonesia. Dalam hal rahasia dagang, perjanjian franchise Cocoyo sendiri tidak mengatur mengenai bentuk rahasia dagang dan klausula untuk tidak membocorkan rahasia dagang tersebut. Rahasia dagang dan kewajiban untuk tidak membocorkan rahasia dagang tersebut diberikan oleh pihak pertama kepada pihak kedua hanya secara lisan. Dalam PP Waralaba sendiri pun tidak

12 Indira Swasti Gama Bhakti, 'Rahasia Dagang dalam Usaha Franchise di Bidang Kuliner' (2017)

1 (1) Literasi Hukum 13, 18.

Pasal 1 Undang-Undang No. 30 Tahun 2000 tentang Rahasia Dagang.

Pasal 5 Undang-Undang No. 30 Tahun 2000 tentang Rahasia Dagang.

Pasal 3 Peraturan Pemerintah Republik Indonesia No. 42 Tahun 2007 tentang Waralaba. 
mengharuskan perlunya dicantumkan pengaturan mengenai rahasia dagang dalam perjanjian franchise. Apabila dilihat dari perjanjian franchise Cocoyo sendiri, perjanjian ini tidak memberikan perlindungan bagi rahasia dagang Cocoyo. Dengan tidak adanya pengaturan mengenai rahasia dagang dalam perjanjian franchise, hal ini dapat menimbulkan kerugian bagi pemilik rahasia dagang. Jika dilihat dari perjanjian franchise sesama usaha $F \& B$ seperti Dobbi Fried Chicken, walaupun dalam perjanjian franchise sudah dituliskan mengenai pengaturan rahasia dagang namun pada nyatanya tetap ada franchisee yang melanggar hal tersebut sehingga franchisor Dobbi Fried Chicken harus memutuskan kontrak atau menghentikan semua perbuatan franchisee yang mengungkapkan rahasia dagang dan merugikan franchisor Dobbi Fried Chicken. ${ }^{16}$ Dari hal ini, Penulis melihat bahwa dengan adanya pengaturan mengenai rahasia dagang yang tercantum dalam perjanjian franchise masih ada yang melakukan pelanggaran dengan mengungkapkan rahasia dagang kepada pihak lain. Sehingga, menurut Penulis perlu adanya pengaturan mengenai adanya pencantuman rahasia dagang dalam perjanjian franchise.

Berdasarkan latar belakang di atas, Penulis tertarik untuk mengkaji dan meneliti lebih dalam mengenai bentuk perlindungan hukum rahasia dagang dalam perjanjian franchise, khususnya dalam perjanjian franchise Cocoyo. Sehingga, dirumuskan masalah yaitu bagaimana bentuk perlindungan hukum terhadap rahasia dagang dalam perjanjian franchise Cocoyo.

Penelitian yang digunakan adalah penelitian hukum normatif, atau yang sering disebut dengan penelitian kepustakaan. Penelitian ini merupakan penelitian yang sangat erat dengan kepustakaan karena akan membutuhkan data-data yang bersifat sekunder yang bersumber dari kepustakaan. Penelitian ini akan mengkaji hukum dari berbagai aspek seperti aspek teori, filosofi, struktur, konsistensi, penjelasan umum dan penjelasan tiap pasal, formalitas dan kekuatan yang mengikat suatu undang-undang, serta bahasa yang digunakan. Sehingga, penelitian normative akan berobjek pada doktrin, asas, dan prinsip hukum.

Penelitian akan mengkaji UU Rahasia Dagang sebagai payung hukum dari rahasia dagang yang merupakan salah satu klausula penting dalam perjanjian franchise. Kemudian mengkaji PP Waralaba dan Peraturan Menteri Perdagangan RI No. 71 Tahun 2019 tentang Penyelenggaraan Waralaba sebagai tonggak dari kedudukan rahasia dagang dalam perjanjian franchise. Penulis akan meneliti kajian dari beberapa peraturan tersebut dan menghubungkan dengan fakta hukum yang ada sehingga akan dihasilkan data untuk bahan penulisan.

\section{PEMBAHASAN}

\section{Rahasia Dagang Menurut UU Rahasia Dagang}

Rahasia dagang adalah salah satu dari berbagai banyaknya hak kekayaan industri yang terkandung dalam hak kekayaan intelektual. Rahasia dagang diatur dalam UU Rahasia Dagang yang melalui peraturan perundang-undangan ini memberikan perlindungan hukum terhadap rahasia dagang. Rahasia dagang sendiri merupakan informasi di bidang teknologi atau bisnis yang bersifat rahasia dan

16 Amirah, Ahmadi Miru, dan Nurfaidah Said, 'Perlindungan Hukum Rahasia Dagang Dalam Perjanjian Kerjasama Waralaba' [2013] Program Pascasarjana Universitas Hasanuddin 9. 
memiliki nilai ekonomis karena hal inilah yang membedakan karakteristik dari satu pelaku usaha dengan pelaku usaha lainnya. Oleh karena itu, rahasia dagang harus dijaga kerahasiaannya dari pihak luar. ${ }^{17}$ Dalam UU Rahasia Dagang disebutkan bahwa rahasia dagang meliputi metode produksi, metode pengolahan, metode penjualan, atau informasi dalam bidang teknologi atau bisnis lain yang memiliki nilai ekonomis. Informasi-informasi lain ini dapat berupa informasi yang berkaitan dengan teknologi organik, seperti produk perawatan kecantikan, produk rumah tangga, resep produk makanan dan minuman; informasi yang berkaitan dengan teknologi canggih seperti chips, teknik produksi dalam pabrik, program komputer, proses fotografi, data pengujian produk farmasi; informasi yang berkaitan dengan metode dagang atau bisnis seperti data tentang biaya produksi dan harga, materi promosi yang belum dipublikasikan, teknik marketing dan data demografis, proses produksi dan penyiapan makanan, metode pembelajaran; informasi yang berkaitan dengan daftar langganan seperti informasi rute perjalanan salesman, data mail order, sifat-sifat dan uraian demografis tentang para pelanggan; dan informasi yang berkaitan dengan pengetahuan bisnis seperti jadwal pasokan suku cadang, alternatif pemasok suku cadang, nama-nama pengambil keputusan dalam perusahaan langganan. ${ }^{18}$

Dalam Pasal 1 angka (1) UU Rahasia Dagang, rahasia dagang disebutkan sebagai informasi yang tidak diketahui oleh umum di bidang teknologi dan/atau bisnis, mempunyai nilai ekonomi karena berguna dalam kegiatan usaha, dan dijaga kerahasiaannya oleh pemilik rahasia dagang, dari penjelasan ini dapat ditarik tiga unsur penting dalam suatu rahasia dagang:

a. Rahasia dagang harus merupakan suatu "informasi" baik di bidang teknologi ataupun bisnis seperti daftar pelanggan, resep makanan dan minuman, komposisi obat, dan serta proses-proses internal untuk menghasilkan suatu produk atau jasa.

b. Rahasia dagang harus memiliki nilai ekonomis yang berguna dalam kegiatan usaha.

c. Rahasia dagang tersebut harus dijaga kerahasiaannya oleh pemilik rahasia dagang. Kerahasiaan tersebut juga harus dijaga sebagaimana mestinya, yang memiliki arti semua langkah yang menurut ukuran kewajaran, kelayakan, dan kepatutan yang harus dilakukan.

Apabila ketiga unsur ini dipenuhi, maka suatu rahasia dagang dapat memperoleh perlindungan hukum. ${ }^{19}$ Perlindungan rahasia dagang sendiri bersifat secara otomatis tanpa harus didaftarkan apabila memenuhi ketiga unsur yang telah disebutkan diatas. Perlindungan rahasia dagang juga tidak memiliki ketentuan yang membatasi tentang jangka waktu berlakunya perlindungan rahasia dagang. Sudarmanto menyebutkan bahwa selama pemilik rahasia dagang tetap merahasiakan dan melakukan usaha-usaha untuk melindungi kerahasian rahasia

17 Andry Setiawan, Dewi Sulistianingsih, dan Rindia Fanny, 'Eksistensi Pendaftaran Rahasia Dagang dan Implementasi Perlindungannya (Studi di Kanwil Kemenkumham Jawa Tengah' (2018) 3 (2) Jurnal Law \& Justice 73, 76.

18 Rudi Agustian, Kompilasi Rubrik Konsultasi Hak Kekayaan Intelektual (RAH\&Partners Law Firm 2009) 92-93.

19 Endang Purwaningsih, Hak Kekayaan Intelektual (HKI) dan Lisensi (Mandar Maju Bandung, 2012) 100. 
dagang, maka selama itu pula berlaku perlindungan hukum. ${ }^{20}$ Rahasia dagang juga tidak perlu didaftarkan untuk mendapatkan perlindungan hukum, karena undangundang secara langsung melindungi rahasia dagang tersebut apabila informasi tersebut bersifat rahasia, mempunyai nilai ekonomi, dan dijaga kerahasiaannya melalui upaya sebagaimana mestinya. ${ }^{21}$

Rahasia dagang ini dapat dimiliki dan digunakan sendiri oleh pemiliknya atau pemiliknya dapat memberikan lisensi kepada orang lain untuk menggunakan rahasia dagangnya. Pemilik juga dapat melarang orang lain untuk membocorkan rahasia dagang milik pemilik kepada pihak yang tidak bersangkutan. Hak rahasia dagang dapat beralih kepada orang lain dengan adanya pewarisan, hibah, wasiat, perjanjian, atau sebab lain yang dibenarkan oleh peraturan perundang-undangan. Pengalihan hak ini harus dalam bentuk tertulis dalam bentuk dokumen pengalihan hak dan wajib dicatatkan pada Direktorat Jendral Hak Kekayaan Intelektual. Pemilik rahasia dagang yang memberikan lisensi kepada pihak lain juga harus dicatatkan pada Direktorat Jendral Hak Kekayaan Intelektual. Dalam hal ini, yang dicatat adalah perjanjian lisensi. Lisensi memiliki perbedaan dengan peralihan hak. Dalam Pasal 1 angka 5 UU Rahasia Dagang, lisensi disebutkan sebagai izin yang diberikan oleh pemegang hak rahasia dagang kepada pihak lain dalam bentuk perjanjian untuk memberikan hak kepada penerima lisensi untuk menikmati manfaat ekonomi dari suatu rahasia dagang yang diberi perlindungan dalam jangka waktu tertentu dan syarat tertentu. Sedangkan, peralihan hak rahasia dagang berarti hak rahasia dagang tersebut beralih kepada pemilik hak yang baru dengan didasari dengan pewarisan, hibah, wasiat, atau perjanjian tertulis.

Dalam beberapa kasus, terdapat pengalihan hak rahasia dagang dan perjanjian lisensi yang tidak dicatatkan pada Direktorat Jendral Hak Kekayaan Intelektual. Biasanya hal ini terjadi pada beberapa usaha kecil, seperti Cocoyo. Apabila pengalihan hak rahasia dagang dan perjanjian lisensi tidak dicatatkan, maka konsekuensinya adalah tidak memiliki akibat hukum terhadap pihak ketiga.

Pemegang hak rahasia dagang atau penerima lisensi dapat menggugat siapa saja yang dengan sengaja dan tanpa hak memberikan lisensi untuk menggunakan rahasia dagang atau mengungkapkan rahasia dagang kepada pihak ketiga untuk kepentingan komersial. Gugatan ini dapat berupa gugatan ganti rugi atas perbuatan melawan hukum.22

Dalam Pasal 11-14 UU Rahasia Dagang dinyatakan bahwa pemegang hak rahasia dagang memiliki suatu monopoli atau hak eksklusif dimana pemegang hak rahasia dagang dapat mempergunakan sendiri rahasia dagang yang dimilikinya dan memberikan lisensi kepada pihak lain atau melarang siapa pun untuk menggunakan rahasia dagang atau mengungkapkan rahasia dagang kepada pihak ketiga untuk kepentingan komersial. Sehingga, apabila terjadi pelanggaran rahasia dagang, pemegang hak rahasia dagang dapat mengambil tindakan hukum pidana ataupun keperdataan. ${ }^{23}$

\footnotetext{
20 Sudarmanto, KI dan HKI Serta Implementasinya Bagi Indonesia (PT Elex Media Komputindo, 2012) 94. 
Mengenai pelanggaran rahasia dagang, pelanggaran baru terjadi apabila seseorang dengan sengaja mengungkapkan rahasia dagang, mengingkari perjanjian tertulis atau tidak tertulis untuk menjaga rahasia dagang tersebut. Pelanggaran juga dapat terjadi apabila seseorang memperoleh rahasia dagang dengan cara yang bertentangan dengan peraturan perundang-undangan. Namun, terdapat pengecualian terhadap pelanggaran rahasia dagang, yaitu apabila seseorang dengan sengaja mengungkapkan rahasia dagang semata-mata untuk pertahanan, keamanan, kesehatan atau keselamatan masyarakat. Selain itu, pelanggaran rahasia dagang juga memiliki pengecualian terhadap tindakan rekayasa ulang dari produk yang dihasilkan dari rahasia dagang milik pihak lain untuk kepentingan pengembangan lebih lanjut mengenai produk yang dihasilkan. Yang dimaksud dari tindakan rekayasa ulang adalah tindakan analisis dan evaluasi untuk mengetahui informasi tentang suatu teknologi yang sudah ada. ${ }^{24}$

Pelanggaran rahasia dagang ini juga dilindungi oleh hukum perdata yang merupakan salah satu perbuatan melawan hukum (Pasal 1365 KUHPerdata). Dari pasal ini dapat diketahui bahwa perbuatan yang melanggar hak-hak atas informasi yang bersifat rahasia yang dimiliki oleh seseorang dan memiliki nilai ekonomis merupakan perbuatan yang melanggar hukum, dalam hal ini hukum rahasia dagang. Perbuatan tersebut juga dianggap perbuatan melawan hukum apabila memberikan kerugian bagi pemilik rahasia dagang karena terungkapnya rahasia dagang atau teringkarnya kewajiban tertulis maupun lisan untuk menjaga kerahasiaan tersebut. Sehingga, pihak yang melanggar diwajibkan untuk membayar ganti rugi. ${ }^{25}$

Atas pelanggaran ini, UU Rahasia Dagang juga mengatur mengenai ketentuan pidana apabila melakukan pelanggaran rahasia dagang. Seseorang yang sengaja dan tanpa hak menggunakan rahasia dagang milik orang lain atau mengungkapkan rahasia dagang, mengingkari perjanjian tertulis atau tidak tertulis untuk menjaga rahasia dagang tersebut, dipidana penjara paling lama dua tahun dan atau denda paling banyak Rp.300.000.000,00 (tiga ratus juta rupiah).

\section{Perlindungan Hukum Rahasia Dagang}

Menurut Henry Soelistyo Budi, rahasia dagang tidak perlu didaftarkan kepada instansi manapun untuk mendapatkan perlindungan dan apabila rahasia dagang memiliki ketiga unsur yang terdapat dalam Pasal 1 angka 1 UU Rahasia Dagang, maka rahasia dagang akan secara otomatis mendapatkan perlindungan. Apabila rahasia dagang didaftarkan, maka hal tersebut dapat men-disclose kerahasiaan dari rahasia dagang tersebut dengan menjelaskan rahasia dagang yang dimiliki. Sehingga, hal tersebut bertentangan dengan konsep dasar dari rahasia dagang sendiri. 26

Perlindungan hukum rahasia dagang ini pada dasarnya bersumber pada hubungan keperdataan karena menyangkut hubungan antara dua subjek hukum, yakni pemilik rahasia dagang dengan penerima hak atau lisensi rahasia dagang.

$24 \quad$ Pasal 15 huruf b Penjelasan Undang-Undang No. 30 Tahun 2000 tentang Rahasia Dagang.

25 Anastasia Gerungan, 'Perlindungan Hukum Terhadap Rahasia Dagang Ditinjau dari Aspek Hukum Perdata dan Pidana di Indonesia' (2016) 22 (5) Jurnal Hukum Unsrat 69, 79.

26 Wawancara dengan Henry Soelistyo Budi, Ketua Program Magister Hukum dan Doktor Hukum, Universitas Pelita Harapan (Jakarta, 13 Juli 2020). 
Hubungan keperdataan ini juga biasanya didasarkan pada perjanjian pengalihan hak, lisensi, atau tidak menggunakan dan membocorkan rahasia dagang. Perjanjian ini dibuat oleh pemilik rahasia dagang agar rahasia dagang yang diketahui pihak lawan tetap terjaga kerahasiaannya. Seperti yang tertera dalam Pasal 13 UU Rahasia Dagang, pelanggaran rahasia dagang terjadi apabila seseorang dengan sengaja membocorkan rahasia dagang, dengan mengingkari perjanjian tertulis atau lisan yang ditujukan untuk menjaga kerahasiaan rahasia dagang.

Tidak hanya perjanjian tertulis, namun perjanjian lisan mengenai rahasia dagang juga mendapatkan perlindungan melalui UU Rahasia Dagang. Hal ini dikarenakan tidak semua klausula rahasia dagang ditulis dalam perjanjian, bisa saja klausula tersebut tidak tertulis namun hanya diucapkan secara lisan karena dianggap para pihak telah memiliki pemahaman mengenai hal ini. Contohnya dalam perjanjian franchise. Tidak semua perjanjian franchise memiliki klausula untuk menjaga kerahasiaan rahasia dagang yang tertulis dalam perjanjian. Bahkan dalam PP Waralaba pun tidak mengatur mengenai keharusan adanya klausula rahasia dagang tercantum dalam perjanjian franchise. Namun, hal ini tidak berarti franchisee dapat membocorkan rahasia dagang milik franchisor kepada pihak diluar perjanjian. Antara franchisor dan franchisee telah memiliki pemahaman bahwa rahasia dagang yang dipercayakan kepada franchisee tidak boleh diungkapkan kepada pihak luar tanpa harus dituliskan dalam perjanjian franchise. Hal yang terjadi ini merupakan suatu kebiasaan antara para pihak dalam perjanjian untuk menjaga kerahasiaan rahasia dagang tersebut. Kebiasaan seperti ini diatur dalam Pasal 1347 KUHPerdata yang berbunyi:

"Hal-hal yang menurut kebiasaan selamanya diperjanjikan, dianggap secara diam-diam dimasukan dalam persetujuan, meskipun tidak dengan tegas dinyatakan."

Pasal ini menyatakan bahwa perjanjian tidak hanya mencakup apa yang telah secara eksplisit diperjanjikan, namun juga mencakup kebiasaan-kebiasaan yang tidak tertulis atau secara tegas dinyatakan dalam perjanjian. ${ }^{27}$ Dalam hal ini, sekalipun klausula mengenai kerahasiaan rahasia dagang tidak tertulis secara eksplisit dalam perjanjian, kerahasiaan tersebut tetap akan dilindungi oleh hukum. Sehingga, perjanjian lisan mengenai kerahasiaan rahasia dagang juga ikut terlindungi oleh hukum karena hal ini dianggap sebagai kebiasaan yang melekat dalam melakukan suatu perjanjian franchise.

Dalam hal pembuktian dalam pelanggaran rahasia dagang, pemilik rahasia dagang harus membuktikan penerima rahasia dagang memiliki kewajiban untuk menjaga kerahasiaan rahasia dagang tersebut. Tolak ukur kewajiban untuk menjaga kerahasiaan ini adalah keadaan dimana informasi tersebut diperoleh penerima rahasia dagang. Sebagai contoh, apabila informasi rahasia dagang diperoleh penerima rahasia dagang lewat perjanjian franchise, maka biasanya akan ada klausula mengenai kerahasiaan rahasia dagang dimana franchisee dilarang untuk mengungkapkan rahasia dagang pada pihak lain diluar yang diperjanjikan. Dalam hal ini, karena sudah ada kesepakatan yang mengikat antara kedua pihak tanpa diketahui pihak luar maka franchisee memiliki kewajiban untuk menjaga kerahasiaan tersebut. Sehingga, keadaan dimana informasi diberikan kepada penerima rahasia dagang dalam bentuk perjanjian tertulis merupakan bukti bahwa 
adanya kewajiban untuk menjaga kerahasiaan. Hal ini juga berlaku terhadap perjanjian lisan.

\section{Perjanjian Franchise Cocoyo}

Cocoyo merupakan usaha yang bergerak di bidang $F \& B$. Seperti namanya, Cocoyo hanya menjual produk minuman kelapa murni maupun minuman kelapa yang telah di variasi dengan ditambahkan buah-buahan lain seperti jeruk, alpukat, buah naga, stroberi, manga, nanas, dan markisa. Saat ini, Cocoyo memiliki 12 outlet yang berlokasi di Mall Taman Anggrek, Gandaria City, Pejaten Village, Pluit Village, Living World, Summarecon Mall Bekasi, Botani Square, Plaza Semanggi, Kota Kasablanka, Emporium Pluit Mall, Mall Citraland, dan Artha Gading. Perjanjian Franchise yang diteliti dalam tulisan ini adalah perjanjian franchise gerai Cocoyo di Mall Living World Alam Sutera, antara David Unsulangi yang disebut sebagai pihak pertama (selanjutnya disebut sebagai Principal) dan Ariska Visono yang disebut sebagai pihak kedua (selanjutnya disebut sebagai Partner). Perjanjian franchise ini merupakan perjanjian yang sederhana dengan lima halaman dan hanya terdiri dari tiga bagian, yaitu kewajiban Partner, hak Partner, dan peraturan partnership.

Dalam hal perjanjian franchise Cocoyo, perjanjian ini merupakan perjanjian yang sah di mata hukum karena telah memenuhi empat syarat sah nya perjanjian yang diatur dalam Pasal 1320 KUHPerdata. Perjanjian franchise Cocoyo merupakan perjanjian innominaat bersifat khusus karena tunduk terhadap perundangundangan yang mengatur mengenai perjanjian tersebut. Apabila sebuah perjanjian tidak memiliki peraturan perundang-undangan yang mengaturnya, maka perjanjian tersebut mengacu pada peraturan yang bersifat umum, yaitu KUHPerdata. ${ }^{28}$

Sesuai dengan definisi franchise dalam Pasal 1 PP Waralaba, perjanjian franchise Cocoyo dapat disebut sebagai franchise karena Principal selaku pemilik Cocoyo memiliki hak khusus terhadap sistem bisnis dan memiliki ciri khas dalam usaha penjualan produknya berupa design merek yang khas dan dikenal oleh masyarakat dan resep dalam pembuatan produk minumannya. Cocoyo juga terbukti berhasil dalam dunia bisnis sehingga Principal berani untuk menawarkan mereknya untuk franchise. Cocoyo sendiri juga merupakan bukti nyata dari franchise dengan adanya pemberian hak dari Principal kepada Partner yang didasari dengan perjanjian franchise yang terlampir.

Perjanjian franchise Cocoyo juga telah memenuhi beberapa unsur dari franchise:

a. Adanya subjek hukum, yaitu franchisor dan franchisee;

b. Adanya lisensi atas merek barang atau jasa;

c. Untuk jangka waktu tertentu;

d. Adanya pembayaran royalti.

Secara umum, perjanjian franchise mengandung unsur merek dagang dan rahasia dagang karena perjanjian franchise dapat dikatakan berada di antara perjanjian lisensi dan distributor. Hal ini karena dalam perjanjian franchise terdapat pemberian izin oleh franchisor pemegang hak kekayaan intelektual atau know-how kepada franchisee untuk menggunakan hak kekayaan intelektual dalam menjalankan kegiatan franchise. Pemberian izin ini merupakan salah satu unsur 
dalam perjanjian lisensi. Sedangkan, dalam franchise juga ada quality control dari franchisor terhadap produk-produk pemegang lisensi yang harus sama dengan produk-produk lisensor seakan-akan franchisee merupakan distributor franchisor. ${ }^{29}$

Dalam kontrak franchise, franchisee juga wajib untuk membayar royalty fee kepada franchisor atas penggunaan merek dagang dan proses pembuatan produk. Besar dari royalty fee ditetapkan dalam perjanjian. Sering kali, royalty fee ditetapkan bukan berdasarkan dari keuntungan yang didapat, namun berdasarkan jumlah unit. Selain itu, franchisee juga harus memenuhi kewajiban dari franchisor untuk mendesain perusahaannya sedemikian rupa sehingga mirip dengan milik franchisor. Franchisor juga kerap kali memberikan asistensi kepada franchisee dalam sistem manajemennya. Tidak jarang pula franchisor mewajibkan franchisee untuk membeli bahan-bahan dari pemasok yang ditunjuk oleh franchisor untuk pembuatan produknya. Ada juga yang dalam perjanjian franchise disebutkan bahwa franchisor diperbolehkan untuk melakukan auditing keuangan milik franchisee. Hal ini dilakukan atas nama quality control. Dalam hukum kontrak, hal ini disebut sebagai tying-in agreement. 30

Klausula mengenal quality control juga tercantum dalam perjanjian franchise Cocoyo. Principal melakukan quality control terhadap bahan baku dan produk penjualan Partner. Principal juga melakukan quality control dengan mewajibkan Partner untuk membangun outlet Cocoyo berdasarkan design dan gambar yang telah diberikan oleh Principal dan membeli packaging dari Principal. Selain itu, Principal juga wajib untuk memberikan training dan panduan kepada Partner dalam menjalankan franchise. Walaupun begitu, Partner tetap diberi kebebasan dalam membeli bahan-bahan pokok untuk membuat produk. Quality control seperti ini dilakukan Principal sehingga memberikan kesan seakan-akan Partner adalah distributor dari Principal.

Bentuk franchise Cocoyo sendiri adalah business format franchise. Menurut David Hess, bentuk franchise ini adalah bentuk franchise dimana franchisor memberikan seluruh konsep bisnis yang meliputi strategi pemasaran, pedoman, dan standar pengoperasian usaha dan bantuan dalam pengoperasian franchise. Sehingga, franchisee memiliki identitas yang tidak terpisahkan dari franchisor. ${ }^{31}$ Sedangkan, menurut Bryce Webster, business format franchising adalah franchise dengan sistem franchisee mengoperasikan suatu kegiatan bisnis dengan menggunakan nama franchisor. 32 Sebagai imbalan dalam menggunakan nama franchisor, maka franchisee harus mengikuti metode-metode standar pengoperasian dan berada dibawah pengawasan franchisor dalam hal bahan-bahan yang digunakan, pilihan tempat usaha, desain tempat usaha, jam penjualan, dan persyaratan karyawan. Dalam perjanjian franchise Cocoyo, Partner menjalankan bisnis atas nama merek milik Principal. Principal juga memberikan strategi penjualan, standar pengoperasian usaha, metode-metode dalam menjalankan usaha, dan bantuan dalam menjalankan franchise yang harus diikuti oleh Partner. Namun, dalam hal perjanjian franchise Cocoyo, Principal tidak membatasi pemasok

Salim (n 9) 166.

Salim (n 9) 166.

Suharnoko, Hukum Perjanjian: Teori dan Analisa Kasus (Kencana 2004) 83.

Salim (n 9) 169. 
bahan-bahan yang digunakan, pilihan tempat usaha, dan persyaratan karyawan. Sehingga, hal-hal ini diatur sendiri oleh Partner.

\section{Rahasia Dagang Dalam Perjanjian Franchise Cocoyo}

Pada kenyataannya, perjanjian franchise Cocoyo tidak memiliki klausula yang mengatur secara spesifik mengenai apa saja bentuk rahasia dagang yang diberikan kepada Partner dan klausula untuk tidak membocorkan rahasia dagang tersebut pada pihak diluar perjanjian. Rahasia dagang seperti resep, bahan yang digunakan, cara pembuatan produk diberikan secara lisan oleh Principal kepada Partner saat melakukan training.

Dalam perjanjian ini, Principal merupakan pihak yang memegang hak eksklusif dimana Principal dapat mempergunakan sendiri rahasia dagang yang dimilikinya dan memberikan lisensi atau pengalihan hak untuk menggunakan rahasia dagang, sekaligus melarang siapapun untuk menggunakan dan mengungkapkan rahasia dagang. Sehingga, Principal dapat mengambil tindakan hukum apabila terjadi pelanggaran rahasia dagang. Pelanggaran rahasia dagang yang dimaksud dalam Pasal 13 UU Rahasia Dagang adalah jika seseorang dengan sengaja mengungkapkan rahasia dagang, mengingkari perjanjian tertulis atau tidak tertulis untuk menjaga rahasia dagang yang bersangkutan. Klausula mengenai pelanggaran rahasia dagang tidak tertulis dalam perjanjian franchise Cocoyo. Tidak ada klausula yang bicara mengenai kewajiban Partner untuk merahasiakan metode penjualan atau resep dari Cocoyo. Namun, terdapat satu pasal yaitu Pasal 9 Peraturan Partnership yang menyatakan bahwa pihak Partner dilarang menjual menu Cocoyo dengan merek dagang lain. Pasal ini dapat ditafsirkan sebagai larangan dari Principal kepada Partner untuk tidak menggunakan rahasia dagang Cocoyo untuk kegiatan lain diluar dari usaha franchise Cocoyo. Selain itu, hal ini juga dapat diartikan sebagai larangan untuk mengungkapkan rahasia dagang milik Principal kepada pihak lain diluar perjanjian, walaupun hal tersebut tidak secara spesifik disebutkan dalam perjanjian. ${ }^{33}$ Menurut Henry Soelistyo Budi, kewajiban untuk menjaga kerahasiaan rahasia dagang bisa dilakukan secara implisit. Bahkan, hanya dengan simbol menutupkan satu jari pada bibir sudah dapat dikategorikan sebagai kewajiban implisit bagi penerima rahasia dagang untuk menjaga kerahasiaan rahasia dagang. Hal ini yang disebut sebagai duty of care bagi penerima rahasia dagang untuk menjaga kerahasiaan. ${ }^{34}$

Dengan demikian, hal tersebut merupakan salah satu cara bagi Principal untuk menjaga rahasia dagang agar tidak disalahgunakan. Dengan Principal melarang Partner untuk menjual menu Cocoyo dengan merek dagang lain, maka Principal dan Partner akan tetap mendapat keuntungan dari rahasia dagang milik Principal yang dikelola oleh Partner. Apabila Partner melanggar klausula tersebut, maka Partner sendiri yang akan mendapatkan keuntungan dari rahasia dagang milik Principal dan Principal akan mengalami kerugian karena rahasia dagangnya disalahgunakan Partner yang bukan untuk usaha franchise Cocoyo.

33 Syahriyah Semaun, 'Perlindungan Hukum Terhadap Rahasia Dagang' (2011) 9 (1) Jurnal Hukum Diktum 30, 35.

34 Wawancara dengan Henry Soelistyo Budi, Ketua Program Magister Hukum dan Doktor Hukum, Universitas Pelita Harapan (Jakarta, 13 Juli 2020). 
Pemilik rahasia dagang memiliki hak untuk menggunakan sendiri rahasia dagangnya atau memberikan lisensi kepada pihak lain untuk menggunakan rahasia dagangnya. Pemberian lisensi ini diwujudkan dengan adanya perjanjian franchise antara Principal selaku pemilik rahasia dagang yang memberikan izin kepada Partner untuk menikmati manfaat ekonomi atas penggunaan rahasia dagang milik Principal. Dalam hal ini, perjanjian franchise Cocoyo tidak dilaporkan kepada Direktorat Jendral Hak Kekayaan Intelektual, sehingga hal tersebut tidak memiliki akibat hukum kepada pihak ketiga.

Walaupun tidak dilaporkan kepada pihak yang berwenang, rahasia dagang Cocoyo tetap mendapatkan perlindungan hukum. Perlindungan hukum bagi rahasia dagang adalah hal yang penting bagi Principal karena hal tersebut yang menjadi tumpuan dalam menjalankan usaha. Apabila rahasia dagang terungkap pada pihak lain diluar perjanjian, maka dapat menimbulkan kerugian bagi Principal. Dalam hal ini, rahasia dagang Cocoyo mendapatkan perlindungan hukum karena telah memenuhi beberapa unsur yang membuat sebuah rahasia dagang dilindungi oleh UU Rahasia Dagang.

a. Rahasia dagang Cocoyo merupakan suatu informasi yang bersifat rahasia, mempunyai nilai ekonomi, dan dijaga kerahasiaannya.

b. Rahasia dagang Cocoyo merupakan suatu informasi yang bersifat rahasia di bidang bisnis.

c. Rahasia dagang Cocoyo memiliki nilai ekonomi bagi Principal dan Partner untuk menghasilkan keuntungan.

d. Rahasia dagang Cocoyo dijaga kerahasiaannya dengan beberapa orang saja yang tahu, termasuk Principal selaku pemegang hak rahasia dagang dan Partner.

Sesuai dengan apa yang tertera dalam Pasal 3 UU Rahasia Dagang, rahasia dagang Cocoyo tidak perlu didaftarkan atau dilaporkan kepada instansi yang berwenang karena selama rahasia dagang telah memenuhi unsur-unsur yang telah disebutkan, maka rahasia dagang akan secara otomatis mendapatkan perlindungan hukum.

\section{Perlindungan Hukum Rahasia Dagang Perjanjian Franchise Cocoyo}

Walaupun perjanjian franchise Cocoyo tidak memiliki klausula yang secara spesifik mengatur mengenai apa saja rahasia dagang Cocoyo dan peraturan untuk tidak membocorkan rahasia dagang tersebut, nyatanya Principal dan Partner telah melakukan kesepakatan secara lisan agar tidak mengungkapkan rahasia dagang yang digunakan kepada pihak lain. Kesepakatan secara lisan ini disaksikan oleh saksi dari kedua belah pihak. Sehingga, sesuai dengan Pasal 13 UU Rahasia Dagang, apabila Partner dengan sengaja mengungkapkan rahasia dagang dan mengingkari kesepakatan tidak tertulis untuk menjaga rahasia dagang tersebut maka Principal dapat mengambil tindakan hukum.

Dari pasal tersebut, dapat diketahui bahwa kesepakatan secara lisan untuk menjaga kerahasiaan rahasia dagang juga dilindungi oleh hukum, khususnya hukum perdata. Pasal 1347 KUHPerdata mengatur mengenai hal-hal yang tidak dinyatakan secara tegas dalam perjanjian, namun menurut kebiasaan hal tersebut diperjanjikan, maka hal tersebut dianggap sebagai bagian dalam perjanjian. Dalam 
hal ini, Principal tidak memasukan klausula mengenai larangan kepada Partner untuk mengungkapkan rahasia dagang kepada pihak lain diluar perjanjian. Namun, ada pasal dalam perjanjian tersebut yang menyiratkan Partner untuk tidak menggunakan rahasia dagang milik Principal untuk hal lain. Secara umum pun Partner mengetahui bahwa ia tidak boleh membocorkan rahasia dagang milik Principal kepada orang lain dan untuk hal-hal diluar usaha franchise. Principal juga tahu bahwa tanpa dibicarakan lagi, itu sudah menjadi kewajiban Partner untuk menjaga kerahasiaan dari rahasia dagang yang dipercayakan Principal. Sehingga, hal tersebut tidak dicantumkan lagi pada perjanjian franchise dan Principal hanya memberi larangan secara lisan kepada Partner. Hal seperti ini yang dianggap oleh KUHPerdata bahwa larangan secara lisan tersebut merupakan bagian dari perjanjian.

Dari hal tersebut, maka dapat diketahui bahwa rahasia dagang yang diberikan secara lisan dari pemilik rahasia dagang kepada penerima rahasia dagang merupakan hal yang sah dan dilindungi oleh UU Rahasia Dagang dan KUHPerdata. Begitu juga dengan larangan untuk mengungkapkan rahasia dagang. Walaupun dalam perjanjian franchise tidak tertulis secara tegas mengenai larangan untuk mengungkapkan rahasia dagang, tidak berarti franchisee bisa mengungkapkan rahasia dagang tersebut kepada pihak lain diluar perjanjian atau menggunakan rahasia dagang tersebut untuk hal diluar yang diperjanjikan. Apabila franchisor mengatakan kepada franchisee secara lisan untuk menjaga kerahasiaan rahasia dagang tersebut, maka hal tersebut juga sah di mata hukum.

Apabila melihat melalui kacamata peraturan perundang-undangan mengenai franchise, dalam PP Waralaba sendiri yang merupakan dasar hukum pengaturan franchise saat ini di Indonesia tidak membahas secara spesifik mengenai rahasia dagang. Dalam Pasal 3 PP Waralaba hanya disebutkan bahwa franchise harus memenuhi kriteria seperti memiliki ciri khas usaha, terbukti sudah memberikan keuntungan, memiliki standar atas pelayanan dan barang atau jasa yang ditawarkan dibuat secara tertulis, mudah diajarkan dan diaplikasikan, adanya dukungan yang berkesinambungan, dan hak kekayaan intelektual yang telah terdaftar. Dari keenam kriteria ini terdapat dua kriteria yang berhubungan dengan rahasia dagang:

a. Ciri khas usaha

Menurut Penjelasan Pasal 3 PP Waralaba, yang dimaksud dengan ciri khas usaha adalah suatu usaha yang memiliki keunggulan atau perbedaan yang tidak mudah ditiru dibandingkan dengan usaha lain sejenis, dan membuat konsumen selalu mencari ciri khas yang dimaksud. Misalnya, sistem manajemen, cara penjualan dan pelayanan yang merupakan karakteristik khusus dari franchisor. ${ }^{35}$ Apabila dikaitkan dengan perjanjian franchise Cocoyo, maka rahasia dagang dapat dikategorikan ciri khas usaha karena rahasia dagang dari Cocoyo, terutama resep minumannya merupakan hal yang tidak mudah ditiru oleh usaha sejenis dan memiliki cita rasa tersendiri.

b. Hak kekayaan intelektual yang telah terdaftar

Menurut Penjelasan Pasal 3 PP Waralaba, yang dimaksud dengan hal ini adalah hak kekayaan intelektual yang terkait dengan usaha seperti merek, hak 
cipta, paten, dan rahasia dagang, sudah didaftarkan dan mempunyai sertifikat atau sedang dalam proses pendaftaran di instansi yang berwenang. ${ }^{36}$ Kriteria ini jelas menghubungkan dengan rahasia dagang yang merupakan salah satu bentuk hak kekayaan intelektual. Namun, dalam hal ini rahasia dagang tidak perlu didaftarkan kepada instansi yang berwenang.

Dari penjelasan pasal diatas maka jelas bahwa rahasia dagang adalah sebuah elemen atau unsur yang tidak dapat dipisahkan dari franchise. Namun, ketentuan mengenai rahasia dagang, atau secara garis besar hak kekayaan intelektual tidak lagi diatur dalam PP Waralaba. Dalam Pasal 5 PP Waralaba yang mengatur mengenai klausula-klausula apa saja yang harus ada dalam sebuah perjanjian franchise, klausula mengenai hak kekayaan intelektual (merek, hak cipta, rahasia dagang) tidak diatur.

Padahal, rahasia dagang merupakan salah satu klausula yang harus diatur dalam sebuah perjanjian franchise. Hal ini dikarenakan rahasia dagang merupakan asset yang penting dalam kegiatan usaha, terlebih kegiatan usaha $F \& B$. Dalam usaha $F \& B$, rahasia dagang merupakan jantung yang menghidupkan usaha yang harus dijaga kerahasiaannya karena rahasia dagang inilah yang akan membedakan pelaku usaha F\&B satu dengan pelaku usaha $F \& B$ lainnya. Sebagai contoh, meskipun sama-sama memiliki produk ayam goreng, cita rasa ayam goreng milik KFC pasti berbeda dengan ayam goreng milik McDonald's. Dengan demikian, apabila tidak dijaga dengan baik, maka ditakutkan rahasia dagang tersebut dapat terungkap oleh pihak-pihak lain diluar usaha kemudian akan menimbulkan kerugian bagi pemilik rahasia dagang. Kerugian tersebut dapat berupa penggunaan rahasia dagang oleh pihak lain yang tidak bertanggung jawab, dan dari rahasia dagang tersebut didirikan usaha $F \& B$ yang mirip dengan usaha pemilik rahasia dagang. Namun, jika sebuah perjanjian franchise memiliki klausula mengenai pelanggaran rahasia dagang, maka pemilik rahasia dagang memiliki bukti yang nyata secara hitam diatas putih bahwa Partner melanggar rahasia dagang.

Dari hal ini dapat diketahui bahwa klausula rahasia dagang merupakan hal yang penting dan perlu diatur dalam PP Waralaba, atau peraturan perundangundangan lainnya mengenai franchise. Walaupun tidak diwajibkan untuk mencantumkan klausula rahasia dagang dalam perjanjian franchise, namun pada akhirnya Principal dan Partner melakukan kesepakatan secara lisan untuk menjaga kerahasiaan rahasia dagang. Kesepakatan secara lisan seperti ini baik adanya untuk mencegah terjadinya perkara di kemudian hari, namun tidak semua orang akan berpikir untuk mengatasi kekosongan tersebut dengan kesepakatan secara lisan. Ditakutkan, apabila klausula rahasia dagang tidak diatur secara spesifik dalam PP Waralaba atau peraturan lain mengenai franchise, atau franchisor dan franchisee tidak melakukan kesepakatan secara lisan, franchisee menganggap bahwa rahasia dagang dapat diberitahu kepada orang banyak atau digunakan untuk hal lain diluar yang diperjanjikan. Sehingga, untuk meminimalisir pelanggaran rahasia dagang, lebih baik klausula rahasia dagang dicantumkan pada PP Waralaba atau peraturan perundang-undangan lainnya tentang franchise.

36 Ibid. 


\section{PENUTUP}

Rahasia dagang adalah informasi yang tidak diketahui oleh umum di bidang teknologi dan/atau bisnis, mempunyai nilai ekonomi karena berguna dalam kegiatan usaha, dan dijaga kerahasiaannya oleh pemilik rahasia dagang. Rahasia dagang sendiri meliputi metode produksi, metode pengolahan, metode penjualan, atau informasi dalam bidang teknologi atau bisnis lain yang memiliki nilai ekonomis, seperti produk kecantikan, produk rumah tangga, resep produk makanan atau minuman, program komputer, materi promosi yang belum dipublikasikan. Mengenai perlindungan rahasia dagang, apabila rahasia dagang bersifat rahasia, mempunyai nilai ekonomi, dan dijaga kerahasiaannya dengan upaya sebagaimana mestinya, maka rahasia dagang tersebut secara langsung dilindungi oleh UU Rahasia Dagang. Hal ini pun dilindungi oleh Pasal 13 UU Rahasia Dagang dan Pasal 1347 KUHPerdata. Dalam PP Waralaba sendiri, walaupun tidak diatur mengenai adanya keharusan untuk mencantumkan klausula mengenai rahasia dagang dalam perjanjian franchise, namun PP Waralaba mengatur mengenai kriteria yang harus dimiliki apabila mau melakukan franchise, salah satunya adalah dengan memiliki hak kekayaan intelektual seperti merek atau rahasia dagang.

UU Rahasia Dagang sudah mengatur mengenai rahasia dagang secara menyeluruh dan lengkap. Melihat perjanjian franchise Cocoyo, perlu dilakukan amandemen terhadap PP Waralaba untuk menambahkan pasal mengenai pengaturan rahasia dagang dalam perjanjian franchise. PP Waralaba setidaknya harus memiliki pasal yang mengatur mengenai kedudukan rahasia dagang dalam perjanjian franchise, seperti mewajibkan franchisor untuk membuat suatu klausula dalam perjanjiannya mengenai rahasia dagang dan pelanggarannya. Penulis menyarankan untuk menambahkan pasal mengenai ketentuan setelah perjanjian franchise berakhir terlebih dalam hal rahasia dagang. Dengan penambahan pengaturan ini, diharapkan dapat meminimalisir kasus-kasus mengenai penuntutan pembukaan usaha yang sejenis, dan memberikan kepastian hukum bagi pemilik rahasia dagang.

\section{DAFTAR REFERENSI}

\section{Buku}

Agustian R, Kompilasi Rubrik Konsultasi Hak Kekayaan Intelektual (RAH \& Partners Law Firm 2009).

Purwaningsih E, Hak Kekayaan Intelektual (HKI) dan Lisensi (Mandar Maju Bandung 2012).

Salim HS, Perkembangan Hukum Kontrak Innominaat di Indonesia (ed. 3, Sinar Grafika 2005).

Sudarmanto, KI dan HKI Serta Implementasinya Bagi Indonesia (ed. 1, PT Elex Media Komputindo 2012).

Suharnoko, Hukum Perjanjian: Teori dan Analisa Kasus (ed. 1, Kencana 2004).

Saidin HO, Aspek Hukum Hak Kekayaan Intelektual (Intelectual Property Rights)

(Ed. 8, Raja Grafindo Persada 2013). 


\section{Artikel Jurnal}

Aidi Z, Farida H, 'Perlindungan Hukum Para Pihak dalam Perjanjian Waralaba Makanan' (2019) 4 (2) Jurnal Cendekia Hukum.

Bhakti ISG, 'Rahasia Dagang dalam Usaha Franchise di Bidang Kuliner' (2017) 1 (1) Literasi Hukum.

Gerungan A, 'Perlindungan Hukum Terhadap Rahasia Dagang Ditinjau dari Aspek Hukum Perdata dan Pidana di Indonesia' (2016) 22 (5) Jurnal Hukum Unsrat.

Indriani $\mathrm{P}$, dan Widyanti $\mathrm{Y}$, 'Prospects Franchise Business Developments in Indonesia (Case Studies of Food Businesses)' [2012] ICEBM UNTAR.

Lannemey, 'Akibat Hukum Pemutusan Perjanjian Franchise Secara Sepihak Oleh Franchisor Sebelum Berakhirnya Kontrak' (2015) 3 (1) Lex Privatum.

Lasamahu F, 'Perlindungan Hukum Terhadap Franchise dalam Perjanjian Waralaba (Studi Kasus: Analisis Putusan Pengadilan antara PT Lingkar Natura Inti dan Natasha Kasakeyan' (2006) 36 (3) Jurnal Hukum dan Pembangunan.

Najib M, 'Urgensi Pengaturan Waralaba dalam Undang-Undang' (2012) 1 (2) Yustisia. Redjeki S, 'Waralaba (Franchise) di Indonesia' (2011) 8 (2) Lex Jurnalica.

Said N, Miru A, Amirah, 'Perlindungan Hukum Rahasia Dagang Dalam Perjanjian Kerjasama Waralaba' [2013] Program Pascasarjana Universitas Hasanuddin.

Semaun S, 'Perlindungan Hukum Terhadap Rahasia Dagang' (2011) 9 (1) Jurnal Hukum Diktum.

Setiawan A, Sulistianingsih D, dan Fanny R, 'Eksistensi Pendaftaran Rahasia Dagang dan Implementasi Perlindungannya (Studi di Kanwil Kemenkumham Jawa Tengah' (2018) 3 (2) Jurnal Law \& Justice.

\section{Website}

Koran Sindo, 'Omzet Rp150 Triliun, Momentum Emas Ekspansi Bisnis Waralaba' (Oke Finance, 22 April 2019) <https://economy.okezone.com/read/ 2019/04/22/320/2046337/omzet-rp150-triliun-momentum-emas-ekspansibisnis-waralaba> diakses 9 September 2020.

Gora Kunjana, 'Waralaba, Kekuatan Baru Ekonomi RI' (Investor Daily Indonesia, 26 November 2016) <https://investor.id/archive/waralaba-kekuatan-baruekonomi-ri> diakses 9 September 2020.

\section{Peraturan Perundang-Undangan}

Kitab Undang-Undang Hukum Perdata.

Undang-Undang No. 30 Tahun 2000 tentang Rahasia Dagang.

Peraturan Pemerintah Republik Indonesia No. 42 Tahun 2007 tentang Waralaba.

Peraturan Menteri Perdagangan Republik Indonesia No. 71 Tahun 2019 tentang Penyelenggaraan Waralaba. 
